\title{
DEURBANIZATION AND THE RIGHT TO THE DEURBANIZED CITY
}

\section{LA DESURBANIZACIÓN Y EL DERECHO A LA CIUDAD DESURBANIZADA}

\author{
Hossein Sadri \\ hosadri@gmail.com
}

Girne American University, Turkey

\section{Abstract}

Cities are historically created as a collaborative work of different generations and derive from the possibilities created bylocal and climatic conditions, social relations and culture. Today, urbanization may appear as a way of organizing everyday hierarchical, exclusive, discriminatory and exploitative life through industrialized mass production of temporary, privatized, homogenized, fragmented, and power-oriented spaces. This mind-set and application generates several social and ecological problems. This article discusses the right to the city concept, and links it to the deurbanization approach as a social and ecological answer to the problems associated with current urban development. The methodology is supported by a review of the literature and an analysis of examples of works created in the De-Urban Design Studio. Results indicate that the deurbanization approach envisions creating resilient, equitable, non-hierarchical cities composed of communities that replace consumption via harmony with nature, that replace individualism and competition viacollaboration and solidarity, and that replace hegemonic relations via an equitable distribution of power.

Keywords: deurbanization, de-urban design, right to the city, city, urbanization

\author{
Senem Zeybekoglu \\ enem.zeybekoglu@gmail.com \\ Girne American University, Turkey
}

\section{Resumen}

Las ciudades se crean históricamente como un trabajo colaborativo de diferentes generaciones y derivan de las posibilidades de las condiciones locales y climáticas, las relaciones sociales y la cultura. Hoy en día, la urbanización puede aparecer como una forma de organizar la vida cotidiana jerárquica, exclusiva, discriminativa y explotadora a través de la producción en masa industrializada de espacios temporales, privatizados, homogeneizados, fragmentados y orientados hacia el poder. Esta mentalidad y aplicación genera varios problemas sociales y ecológicos. Este artículo pretende discutir el concepto de derecho a la ciudad y vincularlo con el enfoque de desurbanización como una respuesta social y ecológica a los problemas de la urbanización actual. La metodología se apoya en la revisión de la literatura y el análisis de ejemplos de los trabajos creados en De-UrbanDesign Studio.Los resultados indican que el enfoque de desurbanización prevé crear ciudades resilientes, equitativas y no jerárquicas, compuestas por comunidades que reemplazan el consumo por la creación en armonía con la naturaleza; que reemplazan el individualismo y la competencia por la colaboración y la solidaridad y que reemplazan las relaciones hegemónicas por la distribución equitativa del poder.

Palabras clave: desurbanización, diseño des-urbano, el derecho a la ciudad, ciudad, urbanización 


\section{Introduction}

Recent studies point out key facts on the rapid growth of urban life, its vulnerability and its hazardous effects on social and ecological entities worldwide. According to the 2018 revision of the UN World Urbanization Prospects, the urban human inhabitants of our planet rose rapidly from 751 million in 1950 to 4.2 billion in 2018 and is expected to become 6.7 billion in 2050 (United Nations, Department of Economic and Social Affairs, 2018). The graphic of the growth in the share of the urban population in different regions, countries and also in the global scale (figure 1) illustrates the steepness of the augmentation and its excessive and accordingly catastrophic transformation especially in the last 200 years (Ritchie and Roser 2018).

\section{Share of the population living in urbanized areas}

Share of the total population, in a particular region or country, who live in urbanized areas.

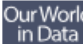

$100 \%$

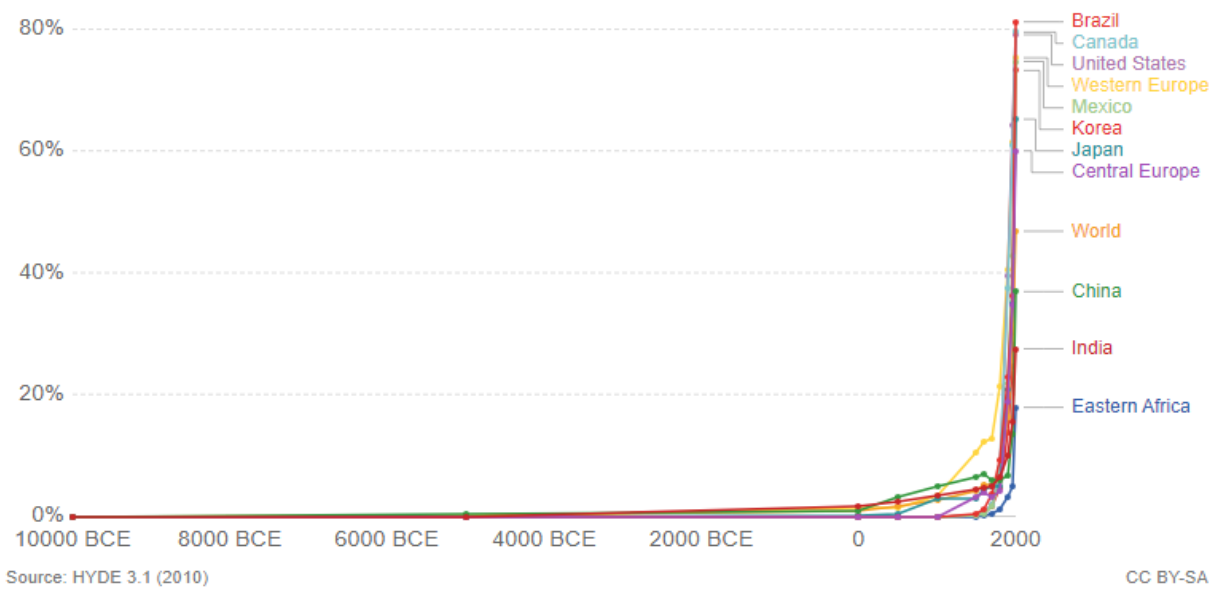

Figure 1: Share of Population Living in Urbanized Areas (Ritchie and Roser 2018).

This rapid urbanization disrupted the balance and turned the resilient, interconnected and harmonious life of our planet to a vulnerable, disconnected and inharmonious one. Prior to this transformation, despite wars, slavery, patriarchy and all other forms of social injustice - because of the very long period of their institution and building -human settlements were resilient structures in balance with nature and for the usage of tens or hundreds of generations. Counter to their hierarchical social systems, these cities had strong social solidarity mechanisms. They had water and food security, and were self-sufficient units with zero carbon footprints. But what these cities have been transformed into is a rapid, destructive and exploitative construction and consumption system, disconnected from nature and the local conditions, temporal, dependent on the limited and vulnerable resources accumulated in billions of years of Earth's life. The fragility of the urban systems is obvious from their weakness against natural disasters (Figure 2), their inherent social inequalities (Figure 3), and their dependency on external sources (Figure 4). 


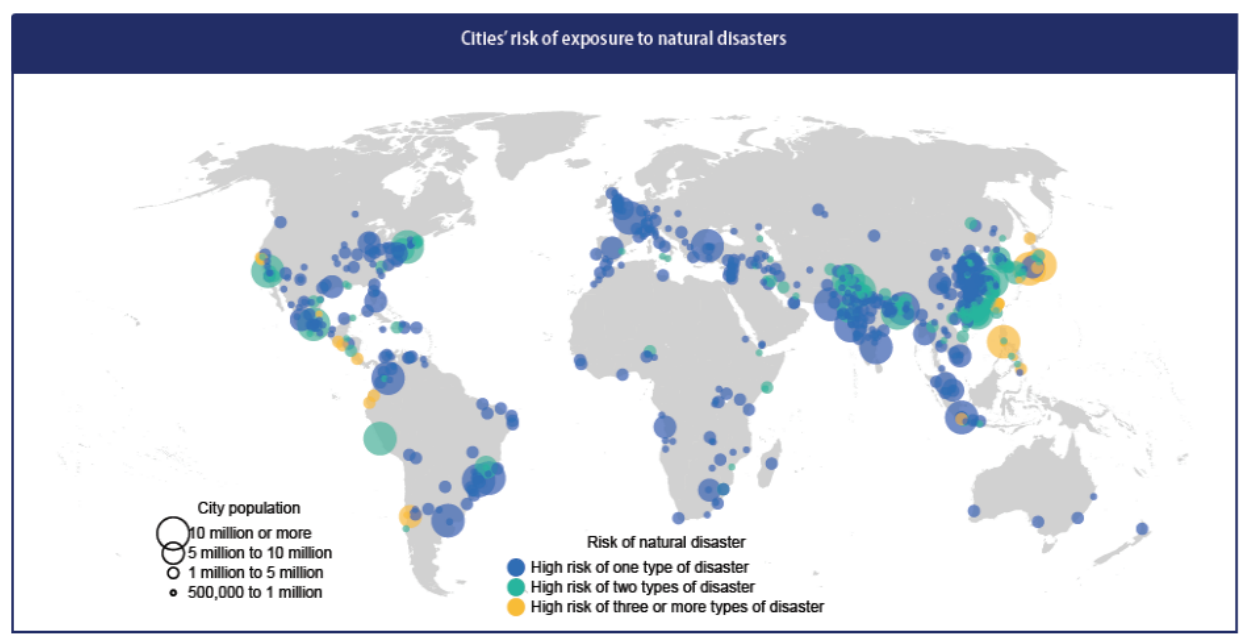

Figure 2: Almost 60 percent of the urban areas with more than 500,000 population in the world is at high risk of exposure to natural disasters (United Nations, Department of Economic and Social Affairs, Population Division, 2018).

\section{New York City's Income Distribution 2009}

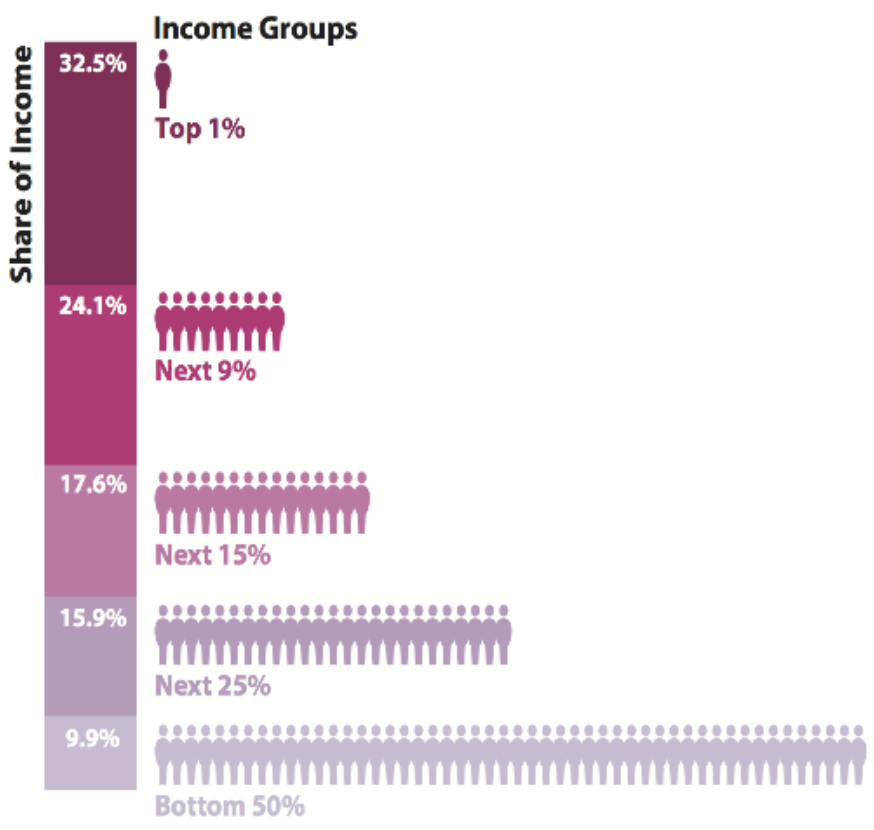

Souce: New YorkCty Comptrolikrs Offlos anatpss based on 2099 New Yark Chy noome Tax Files

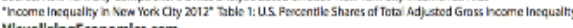
VlsuallzingEconomics.com

Figure 3: The top $10 \%$ of New Yorkers have more income than the other $90 \%$. The graphic shows the income distribution of New York City in 2009 (Mulbrandon, 2012). 


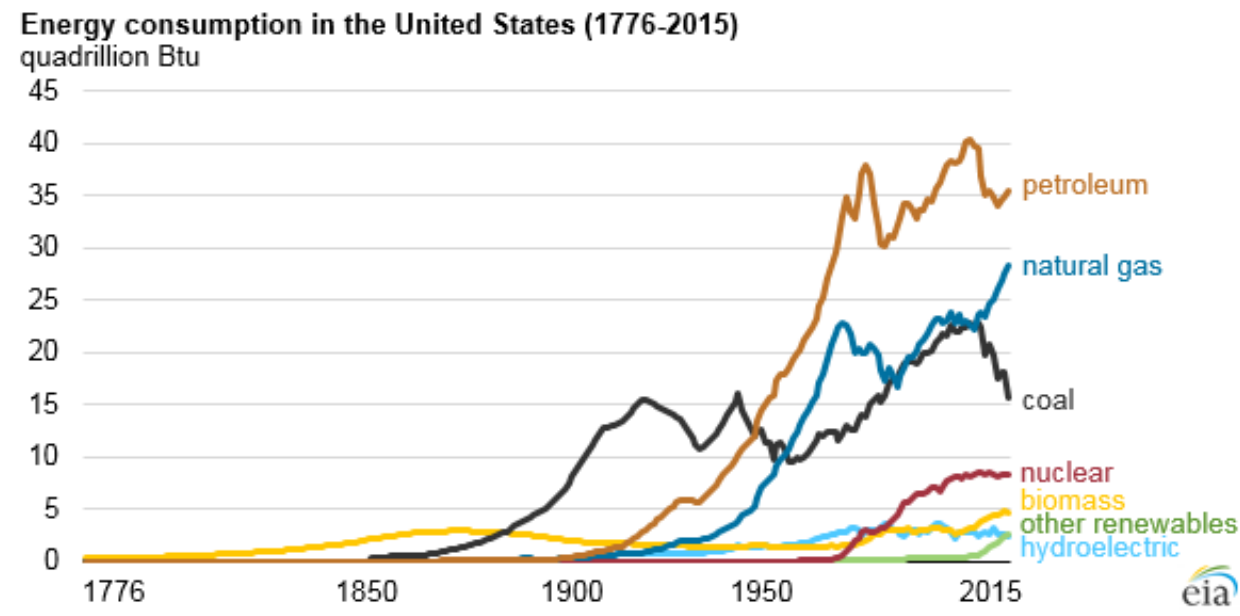

Figure 4: Fossil Energy Sources dominate the US energy consumption in the post industrialization and urbanization period (US Energy Information Administration, 2016).

In addition to the hazardous effects of urbanization on the life of urban human settlers, urbanization and its land conversion mechanism destroys Earth's ecology and reduces livability of the planet for most of its inhabitants. Urbanization breaks the cycles of life, carbon, water, energy, and produces pollution. Accordingly, it increases the ecological footprints of human beings on the earth (figure 5).

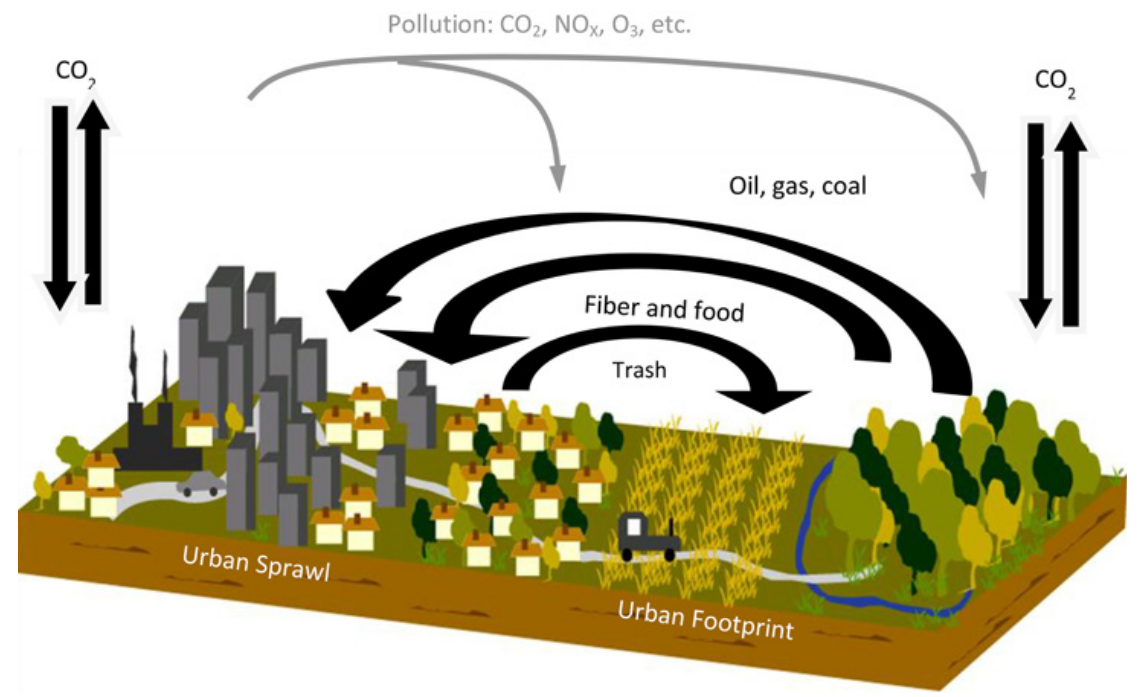

Figure 5: Urban Carbon Cycle (Churkina 2016).

As it is reported by the Researchers of the SETO LAB at Yale University the most crucial impacts of urbanization on the global biosphere are the loss of highly productive lands and vegetation biomass, fragmentation of habitats, reduction of biodiversity, climate change, break in precipitation patterns at scales of hundreds of square kilometers, modification of biogeochemical and hydrologic cycles, and the growth of energy demands (SETO LAB). 


\section{Urbanization of Cities}

Urbanization has an exclusive, massive, short term, rapid, anti-natural and industrial production process. Henri Lefebvre calls this production process as abstraction of space which transforms communal life and nature to abstract, reproducible, repetitive, replaceable "things" with minor use-values and high exchange-values. They are results of the liaison between state, capital and institutional knowledge and accordingly these abstract products serve to these power holders by building hierarchies, homogenizing activities, limiting accesses, restricting everyday life, fragmenting collectivities, and controlling people (Lefebvre, 1968, Purcell, 2003, Sadri and Zeybekoglu Sadri, 2018a, Lefebvre, 1991, Gottdiener, 1993).

Urbanization is the materialization of capitalist / statist life and is produced to support the life of capitalism / state. Accordingly, its (re)production, circulation and more advanced forms of this circulation which is called commerce follows the same process that other goods and commodities follow. And as underlined by Marx, its final result is money or namely capital. That is to say, "this final product of the circulation of commodities is the first form in which capital appears" (Marx, 1887: 104). Therefore capitalism and urbanization are products of each other and all their sub products such as exploitation of vulnerable people, commodification and pollution of nature, and accumulation of power are results of this circle of production. In contrast to urbanization, cities are places of communal lives made conveniently with the needs of diverse people of various generations and are formed through collective praxis of numerous contributors during centuries. Similar to the creation mechanism in nature, the result of this spontaneous process is also unique and irreplaceable works (Lefebvre, 1991).

Cities are resilient, self-sufficient, autonomous, ecologically adaptive, humanly scaled, and ethical human settlements, where inhabitants enjoyed collaboration, solidarity, and participation and are connected to nature through their social, cultural, and economic activities. As it is clearly underlined by Peter Marcuse, this is a vision for the future and such an ideal city has never existed (Marcuse, 2012). However, both Bookchin and Lefebvre claim that the cities of the pre-capitalist world in some degree could achieve these qualities. In his book Urbanization without Cities (1992), Bookchin indicates that the pre-capitalist cities did not constitute a threat to their environments. On the contrary, they unified with their natural environments in such ingenious ways that would nurture both the city and the nature. In this sense, Bookchin calls cities in history as "ecocommunities" (Bookchin, 1992: ix) or "ethical unions of people" (Bookchin, 1992: x), which integrate the best parts of the "first nature (biological nature)" and the "second nature (social nature)" (Bookchin, 1992: xvii). This integration was possible through an "ethics of complementarity" (Bookchin, 1992: xviii), a guiding principle that drove the actions of the inhabitants of cities of an ecological society in the past (Bookchin, 1992). "In such an ethics, human beings would complement nonhuman beings with their own capacities to produce a richer, creative, and developmental whole - not as a "dominant" species but as supportive one" (Bookchin 2006; p: 21).

However, with the impacts of industrialization and massive urbanization, cities have transformed into huge agglomerations of buildings and people, arranged according to the needs of capitalist economic system, a system based on destruction of nature and consumption of resources, goods and services, all tangible and intangible aspects of city life including human relations. Provision of basic human needs, from shelter to nutrition, have become dependent on consumption of non-renewable energies, 
destruction of farmlands, forests, ecosystems and natural habitats of indigenous communities all around the world. Bookchin defines urbanization as a "social cannibalism" (Bookchin, 1992: 3) which ruins not only the city but also the country in ecological and agricultural terms, and destroys all kinds of ethical relationships that human beings have established with nature and other human beings. In his words,

"City space with its human propinquity, distinctive neighborhoods, and humanly scaled politics -like rural space, with its closeness to nature, its high sense of mutual aid, and its strong family relationships - is being absorbed by urbanization, with its smothering traits of anonymity, homogenization, and institutional gigantism" (Bookchin, 1992: 3).

With this mutation of cities of ecological societies into urban agglomerations of capitalist societies, contemporary urban areas became showcases for entrepreneurial urban managements. The success of these mutant urban areas and the quality of life in them started to be measured by quantitative terms, such as municipal services, or the amount of mega-projects built in them (Bookchin, 1992). Rather than serving the real needs of urban inhabitants, architectural and urban design, similar to other spatial design practices, have become a tool for this entrepreneurial management approach, producing globalized spaces of capitalist production and mass consumption without any regard to existing local ecological, environmental, social and cultural context of any urban area.

According to Bookchin (1992), not only urban managements, but also urban inhabitants are haunted by this spirit of entrepreneurialism. Traditional connections between historical cities and citizens based on cultural, ethical and ecological values, together with spiritual and civic attachment, have been replaced by materialistic values based on economic gain, consumption and instantaneous bodily pleasures. Bookchin mentions the political and psychological consequences of such a shift in the relationships we have with the settlements we are living in. In today's urban areas, participation of inhabitants in the decision making processes of urban life is reduced to mere voting in the elections of managerial candidates. These representatives have the power of decision making and execution on behalf of their constituencies. Therefore, urban inhabitants view their position as "taxpayers" or "constituents" (Bookchin, 1992: 11), rather than citizens (or citadins) with social power and responsibility in decision making processes of the governance of the urban areas they are living in. Individuals who are destitute of their social powers become more hesitant in making decisions and taking actions about problems of their own and of their environments. Under these circumstances, the social sphere starts to be viewed as a resource of ideological discrepancies that penetrate into the private realm of individuals, rather than a common ground for communal decision making and action. Collapse of the social sphere deeply influences the intellectual world of individuals by destroying their humanity and individuality. According to Bookchin, social disempowerment of individuals leads to a feeling of individual inefficiency and alienation from public matters, thus deprives them of intellectual skills required for producing "assured opinions" (Bookchin, 1992: 10).

Bookchin believes that, city and citizenship are "fecund ecological processes" that transform human societies into a "genuine public sphere" and a "vital body politics" (Bookchin, 1992: 11). Therefore, if we want to reverse the ecological and social destruction caused by urbanization in city and countryside, we have to recreate "participatory civic institutions" that once defined "city life and citizenship" (Bookchin, 1992: xxiv). To put it succinctly, 
"... the city was historically the arena for the emergence of such universalistic concepts as 'humanity' - and is potentially the arena for the reemergence of concepts of political self-regulation and citizenship, for the elaboration of social relations, and for the rise of a new civic culture" (Bookchin, 1992: xvi).

\section{The Right to the De-Urbanized City}

Cooperation of multiple generations, reconciliation between diverse groups, and multifarious cultural accumulations arising from spatial demonstration of everyday life are inherent in the creation of participatory civic institutions, accordingly cities and their places. In contrast to urbanized spaces as products, places of cities have ultimate use value and this character of city contrasts with production, money, capital and commerce. Based on these specialties Lefebvre says "cette ville est elle-meme oeuvre" (Lefebvre, 1968: 3, Lefebvre 1991) and names "city" as the collection of these works, oeuvre; the French word which refers to the collection of all works of an artist. Yet, identifying places of everyday life as unique works makes cities oeuvre, simply because they are collections of places which are outcomes of collective creation praxis of different generations of inhabitants of cities during their history. Accordingly, this collaborative and collective creation praxis enables co-existences in cities and provides more dwelling opportunities and appropriation possibilities. Furthermore, the process of creation of oeuvre supports diverse living practices and their appropriation in a city and the diversity of life and its collective impacts encourages the creation of city as an oeuvre (Sadri and Zeybekoglu Sadri, 2012).

Based on this separability of the creation of oeuvre and the appropriation of the city, Lefebvre builds his concept of the Right to the City (Le Droit a La Ville) on the two interdependent rights: the right to oeuvre and the right to appropriation (Lefebvre, 1968).

The existence of all voices in the cityis the art of living collectively and the right to participate in all activities in the city, and this is what Lefebvre calls the Right to Oeuvre. This right addresses the process of production / creation of urban spaces or cities and aims to replace the urbanized spaces as capitalist products with cities as oeuvre, which is created through the multigenerational collective praxis of inhabitants of the city in a harmony with nature (Lefebvre, 1968). De-Urbanization is this shift from urbanized spaces to cities as oeuvre in a transitional process.

The other interdependent part of Right to the City is the Right to Appropriation. Deurbanization and creation of city as an oeuvre, provide a basis for the actualization of different dwelling practices of people, and accordingly, their appropriation of time and space in the city (Lefebvre, 1968). Contrary to the exclusive right to property, the right to appropriation is not only limited with space but also includes time, and it is a collective and inclusive right. According to Mark Purcell this right embraces a collection of rights including but not limited to the right to exist and coexist, to dwell, namely to live, to play and to work in the city, the right to be represented in it, the right to define, form and create it and finally the right to appropriate it. With reference to Karl Marx's concept of use and exchange values, Purcell expresses that the right to appropriation is maximization of the use value of cities above their exchange value. The right to appropriation reimagines power relations and control mechanisms over cities and everyday life and aims to appropriate the power of occupying and subsequently changing cities, their spaces and their destiny from state, capital and institutional knowledge and reorganize it by empowering the inhabitants of the city (Purcell, 2003). 
The right to oeuvre and the right to appropriation are integrally linked. The existence of one supports the realization of the other and without any of them, the other right cannot be fulfilled. A city as oeuvre, created by its inhabitants can be appropriable by them or in other words, people can live freely in a city which they create by themselves. Accordingly the right to the city is the collective right of people to create the city and dwell in it. This city is a city which is freed from existing power relations, urbanization processes and statist or capitalist structures and their relations; in substance, the current urban situation is reversed and as it is clearly underlined by Lefebvre the contours of such a city can be outlined "by imagining the reversal of current situation, by pushing to its limits this inverted image of the world upside down" (Lefebvre, 1996: 172).

\section{Deurbanization and De-Urban Design}

To be able to reverse the socially, ecologically and ethically destructive impacts of urbanization, and achieve the city which can be created as oeuvre and can be appropriated by all inhabitants for their co-existence and co-dwelling, de-urbanization is inevitable. De-Urbanization does not mean de-citification and imposing a rural lifestyle on all cities and urban environments on earth. On the contrary, it means eliminating the ecological, ethical, social, cultural harms that urbanization imposed on the planet, natural ecosystems and human settlements; and regenerating and transforming these human settlements into eco-communities and permanent habitats, which unify harmoniously civic aspects and humanitarian values of city life with nature (Sadri and Zeybekoglu Sadri, 2018b).

"Deurbanization" is a keyword. Its realization needs, and simultaneously has the potential to generate, a paradigm shift and system change. The process and ways to initiate it alter in different times and conditions, and from society to another. However, in all circumstances, actualization of de-urbanization is interdependent to overturning or deactivating the capitalist system, its power relations and current urbanization practices. More than the social procedures required for its lift-off, de-urbanization covers design methods and necessary actions to get through this transition; such as the ecological and communal life restoration, re-establishing human-human and human-nature relations, forming an adequate environment for habitation of all the living beings as inhabitants of the city, and building a ground to be developed and become a permanent habitat by multi-generational collaborations during decades and centuries. De-urban design aims to facilitate these actions (figure 6).

In addition to the field of urban design, de-urban design takes its philosophical background, knowledge base and methodology from two main resources: Permaculture Design and Transition Design.

Permaculture Design is a design discipline, which deals with the ethical design of sustainable human settlements. Here, the permaculture ethics is defined as the care for people, care for earth and fairshare. Design is creating meaningful and fruitful connections between all the components of any system, between cities and communities, or between social and natural elements and factors of any given settlement such as climate, topography, water, soil, ecosystem, biodiversity and the invisible structures of community life. Finally, sustainability means the ability of any system to produce enough energy for its lifetime maintenance and, recycling itself at the end of its lifetime. Permaculture design aims at producing maximum yield (e.g. soil, water, food, energy, social relations) with minimum intervention, while preserving 
and regenerating nature, water, soil and ecosystems (Mollison, 2002). In line with Permaculture Design principles and methodology, de-urbanization also tries to create human settlements and communities that can harvest their own water; produce their own energy and food; regenerate and enrich their natural environments and their ecosystems; establish their own local economies, governmental, social, cultural, educational institutions (invisible structures); and last but not least, ethically connect to each other.

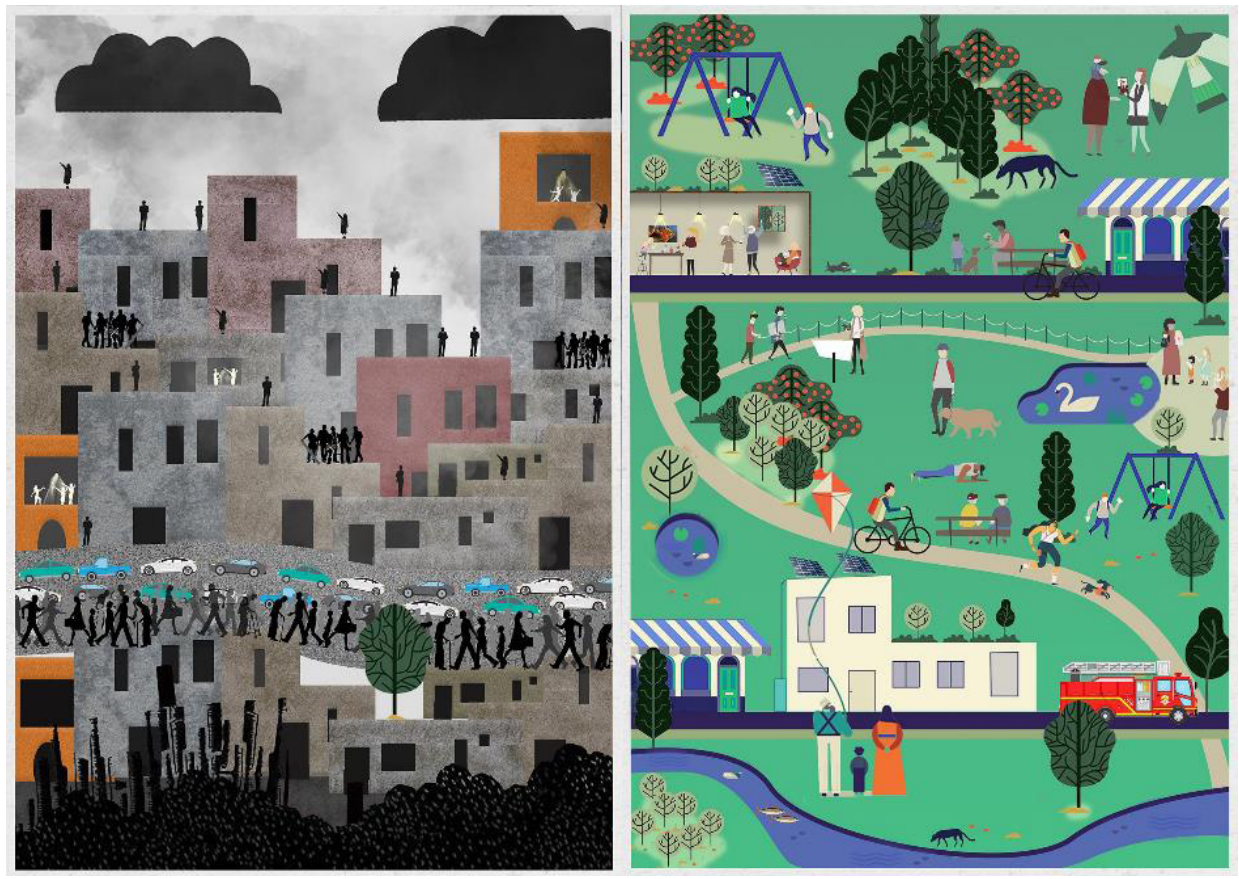

Figure 6: De-urbanized City, De-Urban Design Studio 2018, Drawing by Mohamed Fauzi Ali Bader .

In addition to Permaculture Design, another design philosophy that de-urban design roots in is Transition Design which is highly inspired by the transition town movement, a widespread grassroots movement being adopted by many cities, neighborhoods, university campuses and even workspaces worldwide (Transition Network). Transition town movement aims at eliminating two dreadful threats, and their widespread impacts caused by the contemporary civilization, namely dependency on oil and climate change. Transition movement envisions the formation of resilient, relocalized and sustainable settlements and communities all around the world (Hopkins, 2008). Transition Town Totnes in the UK, the first and one of the most established transition towns in the world has started transition process in 2006, and aims to achieve this vision in 2030 by applying the following strategies: thinking and acting as a community, moving in harmony with nature, building up creative energy systems, promoting localization, nourishing the transition process and empowering individuals and communities (Transition Town Totnes).

Taking into account these two design philosophies and their applications in different localities, de-urban design also deals with designing the process of transformation of current de-humanized, over urbanized, artificial human settlements into ethical permanent habitats, which are democratically controlled by their own inhabitants, 
humanly scaled and functioning within their local ecological limits (Sadri and Zeybekoglu Sadri, 2018b). Considering the current conditions in our urban environments, creating permanent habitats is not a miracle that can happen from today to tomorrow. It requires a vision and a detailed study and design of transition period. The vision project will define the ideal goal based on the climatic, ecological, social, cultural and physical conditions of the specific site (Figure 7).

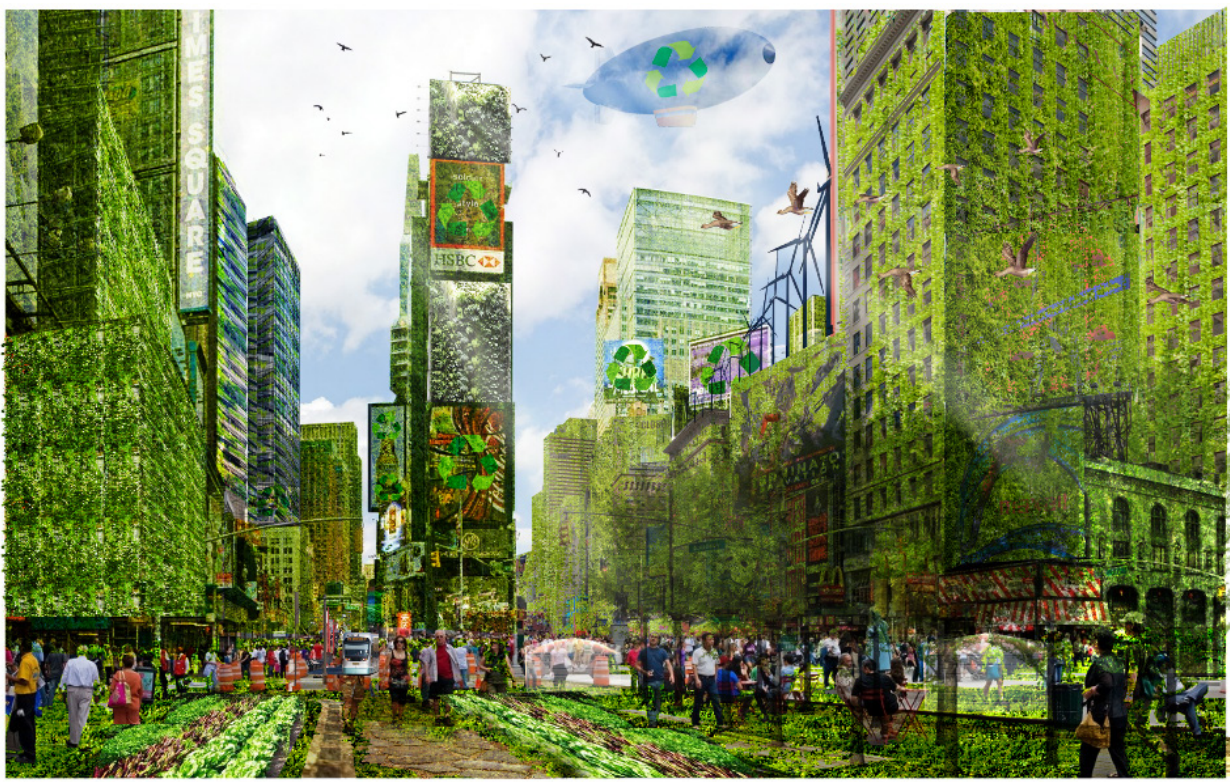

Figure 7: Times Square Vision Project, De-Urban Design Studio 2017, Visualization by Nursultan Eshenaliev.

The transition project contains short term, midterm and long term strategies and projects including analysis of existing problems of any selected area, specification of possible solutions for these problems, creating a long term vision for the future of that area and development of short term and midterm regeneration strategies to be able to reach that long term vision. The long term project envisions a radical shift in planning and organization of our cities that will transform them into resilient, self-sufficient, self-regulating permanent settlements, operating in harmony with nature; developing with respect to their location, local climatic, biological, physical and ecological conditions; and humanly scaled with social-communal institutions that assure democratic participation in decision making processes, just distribution of resources, autonomy and freedom for individuals, and solidarity and mutual trust among community members (Sadri and Zeybekoglu Sadri, 2018b) (Figure 8).

The short term strategies (approximately 5 years) include reducing the damages that we have caused on earth, on ecosystems and human communities due to urbanization. This process aims at understanding the existing situations and problems of any given area, developing responses for these problems according to existing resources and laying foundations for future projects, such as ecological rehabilitation, community building, reducing consumption, creating means of and opportunities for production, and developing local economies, with a special focus on house and street scale. Therefore, initial steps to be taken for the first five years include but not limited to initiating truck gardens and community gardens that can evolve into food forests in 
the following years as a way to start food production, fight pollution and environmental degradation, and as an economic asset for the future; building rainwater harvesting systems in a variety of forms and scales (rainwater tanks, bio-swales, ponds, small dams); initiating grey water and black water recycling systems at street scale; installing clean energy systems to decrease the need for non-renewable energy usage; and organizing neighborhood streets to reduce vehicular traffic and increase bicycle and pedestrian access. Of course all these steps need to be taken together with the support and participation of local people. Therefore creating co-housing units, communal spaces, sharing facilities, informative activities and solidarity networks within the neighborhoods is very crucial in empowering people against hierarchical and dominant power structures, and equipping them with various skills needed for a self-sufficient economy.

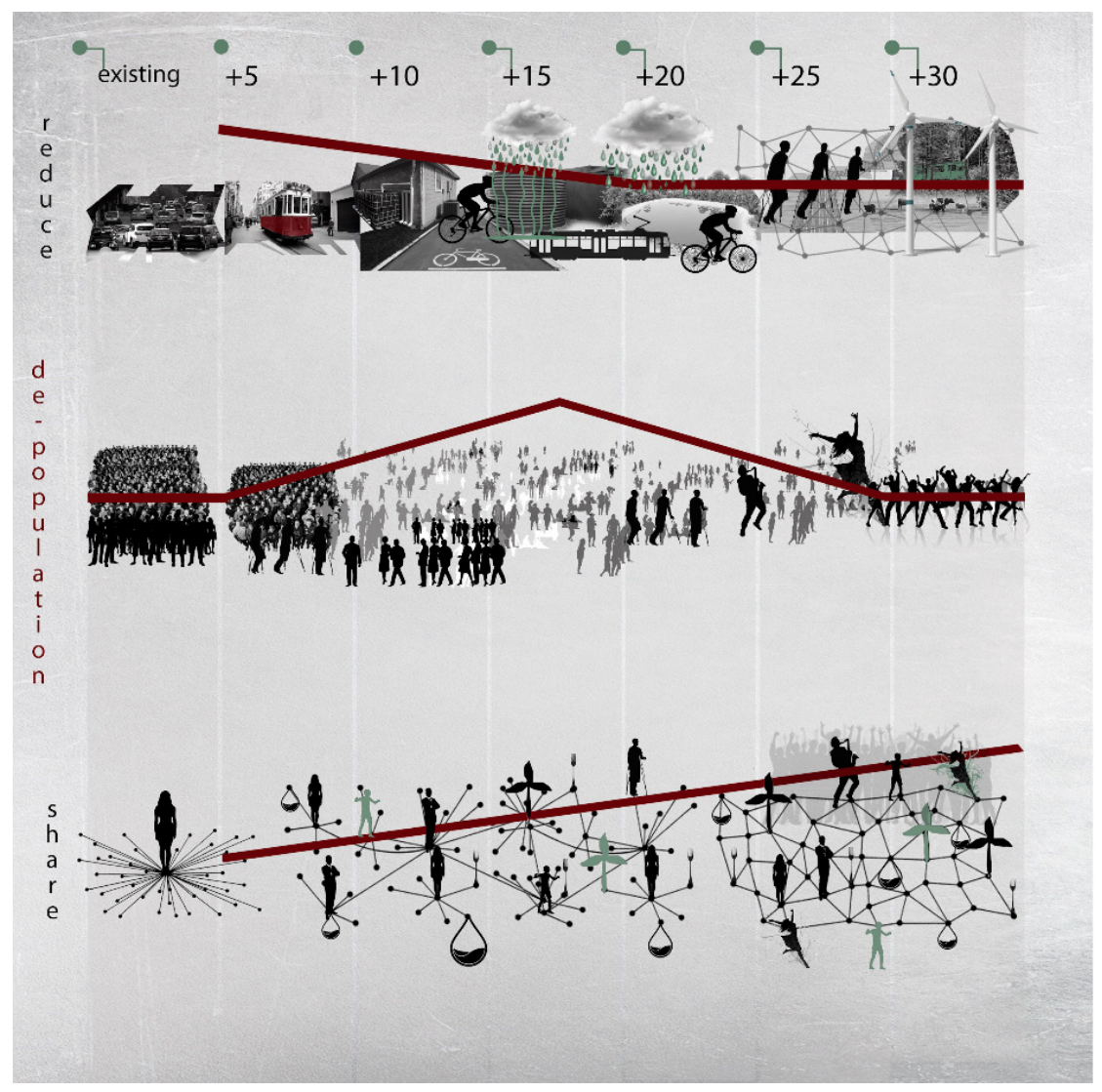

Figure 8: Some of the strategies of De-Urban Design, produced by De-Urban Design Studio, visualized by Serap Sonmez.

Midterm strategies (12-15 years) of de-urbanization are more neighborhood scale oriented and aim at strengthening and enriching facilities, infrastructures, networks and relations initiated in the previous period such as increasing production (of water, food, energy, soil, interactions between people, skills); growing up food forests; building up neighborhood scale communal spaces for educational, commercial, cultural, health and collective decision making facilities. Existing aging buildings can be renovated and re-used for these communal spaces. Reducing motorized traffic 
and developing a clean energy public transportation system is also crucial for this period.

In the long term, (20-30 years) social and ecological results of de-urbanization process is expected to become more explicit, with the growth and establishment of food forests and communal food production networks; recovery and regeneration of ecosystems both for human settlers and wildlife; development of a more local and ecologically sensitive economic system; and transformation of social life. Access to basic needs such as food, water, energy, shelter and services such as education, health, and free and accessible transportation. With a more equitable distribution of resources, all human beings will have the chance to produce, perform, and access to science, technology, arts, and culture (figure 9).

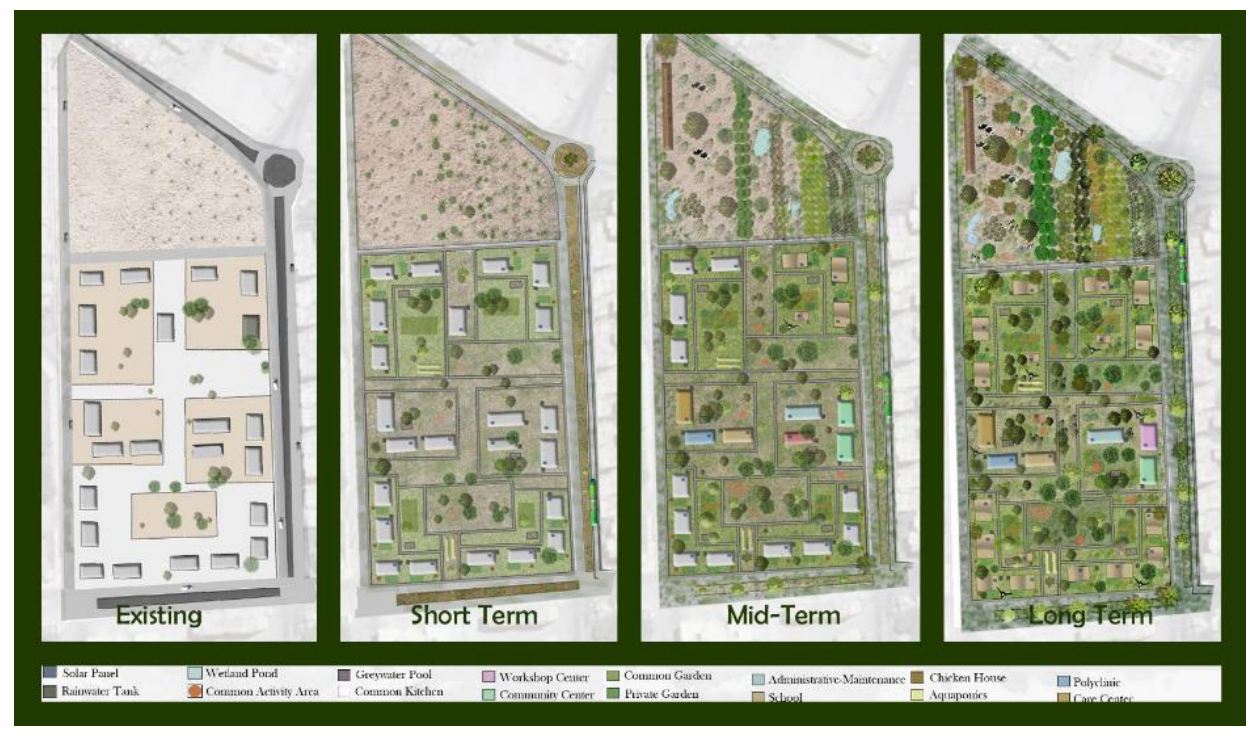

Figure 9:Transition plans for a neighbourhood in Raqqa City in Syria, De-Urban Design Studio 2017, Drawings by Selin Yıldız.

\section{Conclusion}

Originating from the fields of urban design, permaculture design and transition design, de-urban design aims to reverse the process of urbanization of cities and free cities from hegemony of state, capital and institutional knowledge and hand it over to its inhabitants, restore its ecology and community life, and build adequate ground for its future life, succinctly re-imagines cities as re-appropriable permanent habitats and oeuvre. This emerging design discipline tries to deactivate statist and capitalist urbanization and pave the way for the realization of the right to the city, containing two interdependent right to oeuvre and right to appropriation. The fruition of these two rights is precluded by current urbanization processes. And without these two rights the current situation will continue destroying the planet, persecuting living beings, exploiting vulnerable people and stealing our today and tomorrow, dreams, our wills, capabilities and our conscience, values, beliefs hopes and desires for a better world in which everybody can equally live and take the advantages of the productive planet, 
creative human mind, and prosperous culture and knowledge human being could accumulate during the last hundred thousand years.

Acknowledgement: The authors would like to express their special thanks of gratitude to Dr. Fodei Conteh for his thoughtful editing of this paper; also to acknowledge the students who participate in the De-Urban Design Studio during 2017-2018 at Girne American University, Department of Architecture. 


\section{References}

Bookchin, M. (1992). Urbanization without Cities the Rise and Decline of Citizenship (revised edition). Montréal, CA; New York, NY, USA: Black Rose Books.

Bookchin, M. (2006). Social Ecology and Communalism (edited by Eirik Eiglad). Oakland, CA: AK Press.

Churkina, G. (2016). The Role of Urbanization in the Global Carbon Cycle. Frontiers in Ecology and Evolution, 3:144. doi: 10.3389/fevo.2015.00144. Recovered from:

https://www.frontiersin.org/articles/10.3389/fevo.2015.00144/full

Gottdiener, M. (1993). A Marx for Our Time: Henri Lefebvre and the Production of Space. Sociological Theory, 11(1), pp. 129-134.

Hopkins, R. (2008). Transition Handbook: From Oil Dependency to Local Resilience. Foxhole, Dartington, Totnes, Devon, UK: Green Books.

Lefebvre, H. (1968). Le Droit a La Ville. Paris, FR: Anthropos.

Lefebvre, H. (1991). The Production of Space (translated by Donald Nicholson-Smith). Oxford, OX, UK; Cambridge, MA, USA: Blackwell.

Lefebvre, H. (1996). Writings on Cities (translated and edited by E. Kofman and E. Lebas) Malden, MA, USA: Blackwell.

Marcuse, P. (2012), Whose Right(s) to What City? In Cities for People not for Profit: Ciritcal Urban Theory and the Right to the City, edited by: Neil Brenner, Peter Marcuse and Margit Mayer, Routledge, New York.

Marx, Karl. (1887). Capital: A Critical Analysis of Capitalist Production. Translated by Samuel Moore and Edward Aveling. London, LO, UK; Sonnenschein, Lowrey.

Mollison, B. (2002). Permaculture a Designer's Manual (second edition). Victoria, AU: Tagari.

Mulbrandon, C. (2012). Visualizing Economics, Inequality in New York City 2009. Recovered from: http://visualizingeconomics.com/blog/2012/11/4/ inequality-in-new-york-city?rq=new\%20york

Purcell, M. (2003). Citizenship and the Right to the Global City: Reimagining the Capitalist World Order. International Journal of Urban and Regional Research, 27(3/09), pp. 564-590.

Ritchie, H. \& Roser, M. (2018). Urbanization. Recovered from:

https://ourworldindata.org/urbanization

Sadri, H., \& Zeybekoglu Sadri, S. (Oct. 2012). The right to appropriation: Spatial Rights and the Use of Space. In Architecture as a Tool for the Re-appropriation of the Contemporary City Conference. Polis University, Albania.

Sadri, H. \& Zeybekoglu Sadri, S. (2018a). Architecture, City and Human Rights. Girne CYPRUS: Centre for Habitat Studies, Girne American University.

Sadri, H. \& Zeybekoglu Sadri, S. (2018b). Miniatecture: Transition Town Design. Girne CYPRUS: Centre for Habitat Studies, Girne American University.

SETO LAB. (No date). Urbanization and Global Change Environmental Impacts of Urban Growth. Recovered from: https://urban.yale.edu/research/theme-4 
Transition Network. (No date). Who is Involved? Recovered from:

https://transitionnetwork.org/about-the-movement/who-is-involved/

Transition Town Totnes. (No date). Energy Descent Action Plan (EDAP). Recovered from:

https://www.transitiontowntotnes.org/groups/building-and-housing/ energy-descent-action-plan/

United Nations, Department of Economic and Social Affairs, Population Division. (2018). The World's Cities in 2018 - Data Booklet (ST/ESA/ SER.A/417). Recovered from:http://www.un.org/en/events/citiesday/assets/pdf/the_worlds_cities_in_2018_ data_booklet.pdf

United Nations, Department of Economic and Social Affairs. (2018). World Urbanization Prospects: The 2018 Revision Key Facts. Recovered from:

https://population.un.org/wup/Publications/Files/WUP2018-KeyFacts.pdf

US Energy Information Administration. (2016). Today in Energy. Recovered from:https:// www.eia.gov/todayinenergy/detail.php?id=26912 